\title{
Induction of plant defense responses by Ocimum gratissimum L. (Lamiaceae) leaf extracts
}

\author{
Flávia Tavares Colpas ${ }^{1}$, Kátia Regina Freitas Schwan-Estrada ${ }^{1 *}$, José Renato Stangarlin², Maria De Lurdes \\ Ferrarese $^{3}$; Carlos Alberto Scapim ${ }^{1}$; Solange Maria Bonaldo ${ }^{1}$
}

${ }^{1}$ Departamento de Agronomia and ${ }^{3}$ Departamento de Bioquímica Universidade Estadual de Maringá (UEM), Av. Colombo 5790, CEP 87.020900, Maringá, PR, Brazil; ²Centro de Ciências Agrárias, UNIOESTE, CEP 85960-000, Mal. Cândido Rondon, PR, Brazil

Author to correspondence: Kátia Regina Freitas Schwan-Estrada. (schwan@wnet.com.br)

Data de chegada: 10/07/2007. Aceito para publicação em: 02/03/2009

\section{ABSTRACT}

Colpas, F.T.; Schwan-Estrada, K.R.F.; Stangarlin, J. R.; Ferrarese, M.L.; Scapim, C.A.; Bonaldo, S.M. Induction of plant defense responses by Ocimum gratissimum L. (Lamiaceae) leaf extracts. Summa Phytopathologica, v.35, n.3, p.191-195, 2009

Aqueous extracts of the leaves of Ocimum gratissimum at 10 , 25,40 and $50 \%(\mathrm{w} / \mathrm{v})$ concentrations induced the production of phytoalexins in soybean cotyledons and sorghum mesocotyls. The aqueous extracts also induced systemic resistance in cucumber to
Colletotrichum lagenarium, reflected by reduction in disease incidence and an increase in chitinase production. Modes of action and the existence of possible elicitors of defense response in $O$. gratissimum leaf extracts are discussed.

Keywords: resistance induced sorghum, soybean, cucumber.

\section{RESUMO}

Colpas, F.T.; Schwan-Estrada, K.R.F.; Stangarlin, J. R.; Ferrarese, M.L.; Scapim, C.A.; Bonaldo, S.M. Indução de mecanismos de defesa em plantas por extrato de Ocimum gratissimum L. (Lamiaceae). Summa Phytopathologica, v.35, n.3, p.191-195, 2009

Extratos aquosos de folhas da planta medicinal Ocimum gratissimum em concentrações de 10, 25, 40 e 50\% (p/v) induziram a produção de gliceolina em cotilédones de soja e de deoxiantocianidinas mesocótilos de sorgo. Os extratos aquosos também induziram resistência sistêmica em pepino contra Colletotrichum lagenarium, refletido na redução da incidência da doença e no aumento da produção de quitinase. O modo de ação e a existência de possíveis elicitores de resposta de defesa nos extratos de folhas de O. gratissimum são discutidos.

Palavras-chave adicionais: resistance induced sorghum, soybean, cucumber.

In agriculture, the active search for bioactive molecules in plants, insects and microorganisms could represent an alternative for disease control, since our continuously selected varieties of plants rapidly become vulnerable to phytopathogenic agents. The most practical and economically viable method for achieving this goal is protecting plants against phytopathogens through effective complete resistance (20).

Induced resistance has been studied in several plant species, and involves the activation of latent resistance mechanisms through various agents, the so called elicitors, resulting in local or systemic responses, such as SAR, a broad, physiological immunity that results from infection with a necrotrophic pathogen $(18 ; 17)$.

Medicinal plants are potential sources of microbiocide compounds, which could be used in the management of plant diseases (5). Ocimum gratissimum is one such species, and its leaf extracts have been successfully tested for the control of several phytopathogenic fungi in vivo and in vitro, including Rhizopus sp., Curvularia lunata, Ustilago maydis and Phytophthora palmivora (3), Aspergillus flavus, A. niger and $R$. solani (2) and Colletotrichum lindemunthianum (1).

A chemical compound will be considered an activator of the SAR response if it induces resistance to the same spectrum of pathogens and the expression of the same biochemical markers as in the biological model and, in addition, has no direct antimicrobial activity (18). In order to investigate if $O$. gratissimum leaf extracts may lead directly to defense response induction in plants, this work reports the production of phytoalexins in soybean and sorghum, and the induction of resistance in cucumber against Colletotrichum lagenarium.

\section{MATERIALS AND METHODS}

\section{Extract preparation}

Aqueous extracts of $O$. gratissimum, were prepared from $50 \mathrm{~g}$ of fresh leaves collected from young plants in spring at Universidade Estadual de Maringá. Leaves were grinded in $100 \mathrm{~mL}$ of distilled water in a blender for $1 \mathrm{~min}$, and the homogenate was filtered subsequently through cheesecloth and Whatman filter papers $n^{\circ} 40$ and $\mathrm{n}^{\circ} 1$. The filtrate $(50 \%$; w/v) was diluted to 10,25 and $40 \%(\mathrm{w} / \mathrm{v})$.

\section{Phytoalexin determination}

Glyceollins were determined according to the methodology proposed by Ayers et al. (1976) in soybean (Glycine max L. Merr.) cotyledons. Cotyledons were detached from 10-day-old seedlings. 
Sections $(0.5 \mathrm{~cm}$ thick and $0.5 \mathrm{~cm}$ in diameter) were cut from the upper surface of each cotyledon. Aliquots of $20 \mathrm{~mL}$ of each aqueous extract $(10,25,40$ or $50 \%$; w/v) were applied on the wounded cotyledons. Distilled water was used as control. The treated cotyledons were incubated in moist filter paper disks in covered Petri plates at 25 ${ }^{\circ} \mathrm{C}$. After $20 \mathrm{~h}$, each set of cotyledons was transferred to $15 \mathrm{~mL}$ of distilled water in Erlenmeyer flasks, and kept under agitation for $1 \mathrm{~h}$ to rinse off the droplets of sample fluid retained on the wound surfaces. Measurements were presented in terms of this wound-droplet solution, with the elicitor activity expressed in terms of absorbance at $285 \mathrm{~nm}$.

The 3-deoxyanthocyanidins in sorghum (Sorghum bicolor L.) mesocotyls were measured as suggested by Nicholson et al. (1987). Seeds were surface sterilized by immersion in an aqueous solution of $10 \%$ sodium hypochlorite for $10 \mathrm{~min}$ and then repeatedly washed to remove residues. Seedlings were grown in the dark for 3 to 4 days between layers of moist germination paper to allow the uniform elongation of mesocotyls. The seedlings were subjected to $4 \mathrm{~h}$ of light to stop elongation. Mesocotyls were excised and transferred to 1.5 $\mathrm{mL}$ tubes ( 3 mesocotyls per tube) containing $1 \mathrm{~mL}$ of each of the aqueous extracts $(10,25,40$ or $50 \%$; w/v) or distilled water (control). Tubes were kept in moist environment at $27^{\circ} \mathrm{C}$. After $60 \mathrm{~h}$, mesocotyls were weighed, cut in three segments and transferred to tubes containing $80 \%$ methanol to extract the phytoalexins. The 3-deoxyanthocyanidins content of the methanolic solution was determined spectrophotometrically at $480 \mathrm{~nm}$ (29). For both systems, a regression analysis was performed using the Program SAEG, with concentration as the independent variable (with five levels: 0, 10, 25, 40 and 50\%) and absorbance as the dependent variable.

\section{Inoculum's production}

Colletotrichum lagenarium was previously isolated from cucumber leaves showing anthracnose symptoms, and cultured in oat-agar medium in Pirex ${ }^{\hat{a}}$ dishes kept under constant light to induce sporulation. An aqueous suspension was prepared by dissolving a sample of the mucilage from a sporulating colony in distilled water. Spores were counted with the aid of a hemocytometer and adjusted to $1 \times 10^{5}$ conidia. $\mathrm{mL}^{-1}(6)$.

\section{Resistance induction experiment}

Cucumber (Cucumis sativus L.) cv. Safira seeds were planted in $1.5 \mathrm{~L}$ plastic pots ( 3 seeds per pot) containing sterilized soil, and kept in a greenhouse. The first true leaves were sprayed until run-off with O. gratissimum aqueous solutions $(10,25,40$ or $50 \%$; w/v), 7, 3, 1 and 0 days before inoculation with a suspension of $C$. lagenarium on the first and second true leaves. Controls consisted of inoculated seedlings, without pretreatment. After 10 days, the number and size of lesions were measured on both leaves, and $2.5 \mathrm{~cm}^{2}$ leaf discs were collected from both leaves for chitinase enzyme analysis. A factorial ANOVA was performed considering extract concentration (with four levels: 10, 25, 40 and 50\%; w/v) and time before inoculation (four levels: 7, 3, 1 and 0 days), followed by a regression analysis.

Chitinase activity was determined according to Wirth and Wolf (1990). Leaf discs were obtained from leaves at the time symptoms were measured ( 10 days after inoculation), homogenized with $4 \mathrm{~mL}$ of $100 \mathrm{mM}$ acetate buffer (pH 5) and filtered through Whatman filter paper $\mathrm{n}^{\circ} 1$ (enzyme solution) (26). CM-chitin-RBV in aqueous solution $\left(0.1 \mathrm{~mL}, 2 \mathrm{mg} \cdot \mathrm{mL}^{-1}\right)$, buffer $(0.1 \mathrm{~mL} ; 0.2 \mathrm{M}$ sodium acetate, $\mathrm{pH} 5)$ and enzyme solution $(0.2 \mathrm{~mL})$ were incubated in reaction caps for $30 \mathrm{~min}$ at $40^{\circ} \mathrm{C}$. The reaction was terminated by the addition of 1 $\mathrm{N} \mathrm{HCl}(0.1 \mathrm{~mL})$, causing precipitation of the non-degraded substrate.
The reaction caps were cooled on ice (10 min) and centrifuged (5000 $\left.\mathrm{g}, 5 \mathrm{~min}, 4{ }^{\circ} \mathrm{C}\right)$. The supernatants were transferred to glass cuvettes and absorbance was measured spectrophotometrically at $550 \mathrm{~nm}$ against a blank prepared similarly but without the addition of enzyme solution during incubation. The specific enzyme activity (EA) was calculated for each repetition according to the equation: $\mathrm{EA}=\mathrm{EU} \times \mathrm{mg}$ protein $^{-1}$, where EU is the enzymatic unit, given by the spectrophotometrical readings divided by 30 (minutes of incubation), and proteins were determined by Bradford's method (7), with bovine serum albumine as a standard.

\section{RESULTS AND DISCUSSION}

In sorghum, all extracts of $O$. gratissimum induced the production of deoxyanthocyanidins showing high values when $40 \%$ concentration was used (Figure 1A). Similarly, in soybean all extracts induced phytoalexins compared with the control (Figure 1B). It was observed that the induction of phytoalexins in soybean was almost 6 times higher than the control when the concentration of $25 \%$ of $O$. gratissimum extracts was used. For both plant species, there was an almost increase in the production of phytoalexins with the less concentrated extracts. Regression analysis showed a theoretical minimum around the $30 \%$ concentration.

For both glyceollin and deoxyanthocianidin, there was an initial increase in phytoalexins production. Such production decreased at the highest extract concentrations possibly because of phytoalexin inactivation, since at least for deoxyanthocyanidins (especially luteolidin) there can be irreversible binding to cell wall debris (23), which cannot be removed or detected. Besides, exceedingly concentrated extracts could be phytotoxic. The small induction observed in the controls could be due to the injury caused during excision $(30 ; 29)$.

For soybean, elicitors have been shown to be predominantly glycosidic. Glyceollins have been traditionally shown to increase in response to preparations obtained from Phytophthora spp. (16), M. ramossimus (25) and Diaporthe phaseolorum f.sp. meridionalis (21), as well as to plant extracts, such as Alibertia myrcifolia and Rudgea jasminoides (Rubiaceae) (8) and Eucalyptus citriodora (Myrtaceae) (6).

Extracts prepared with $O$. gratissimum leaves were rich in proteins and formed by distinct fractions containing several polar compounds and/or essential oils, such as geraniol and nerol (10). Since composition suggests different molecules or mixtures of molecules may trigger defense responses in sorghum and soybean. Yet, cell walls may contain cellulose, hemicelluloses, pectic compounds, lignin, suberin and proteins, and their proportions may vary among species and between primary and secondary cell walls in the same species (11). Therefore these substances could also be released when cell walls are injured during extract preparation.

For cucumbers grown in the greenhouse, typical anthracnose symptoms developed after $C$. lagenarium inoculation, with lesions being mainly small chlorotic spots and necrosis being observed at leaf margins. Extracts of $O$. gratissimum led to a systemic response, since the second leaves had a smaller number (Table 1), especially when the first leaves were treated 3 days before inoculation. Chitinase activity at the second true leaves was significantly affected by both time and concentration, with maximum production following treatment with the $25 \%$ extract, 1 day before inoculation (Table 2).

In the cucumber seedlings, the number of lesions was significantly 
Table 1. Number of lesions caused by Colletotrichum lagenarium on the first and second true leaves of cucumber seedlings treated with Ocimum gratissimum leaf extracts. Aqueous extracts were applied on the first true leaves $7,3,1$ and 0 days before inoculation of both leaves with a suspension of $1 \times 10^{5}$ conidia. $\mathrm{mL}^{-1}$. Symptoms were measured on the first and second true leaves 10 days after inoculation. Concentration effects were not statistically significant. Values are means of four repetitions, followed by standard deviations.
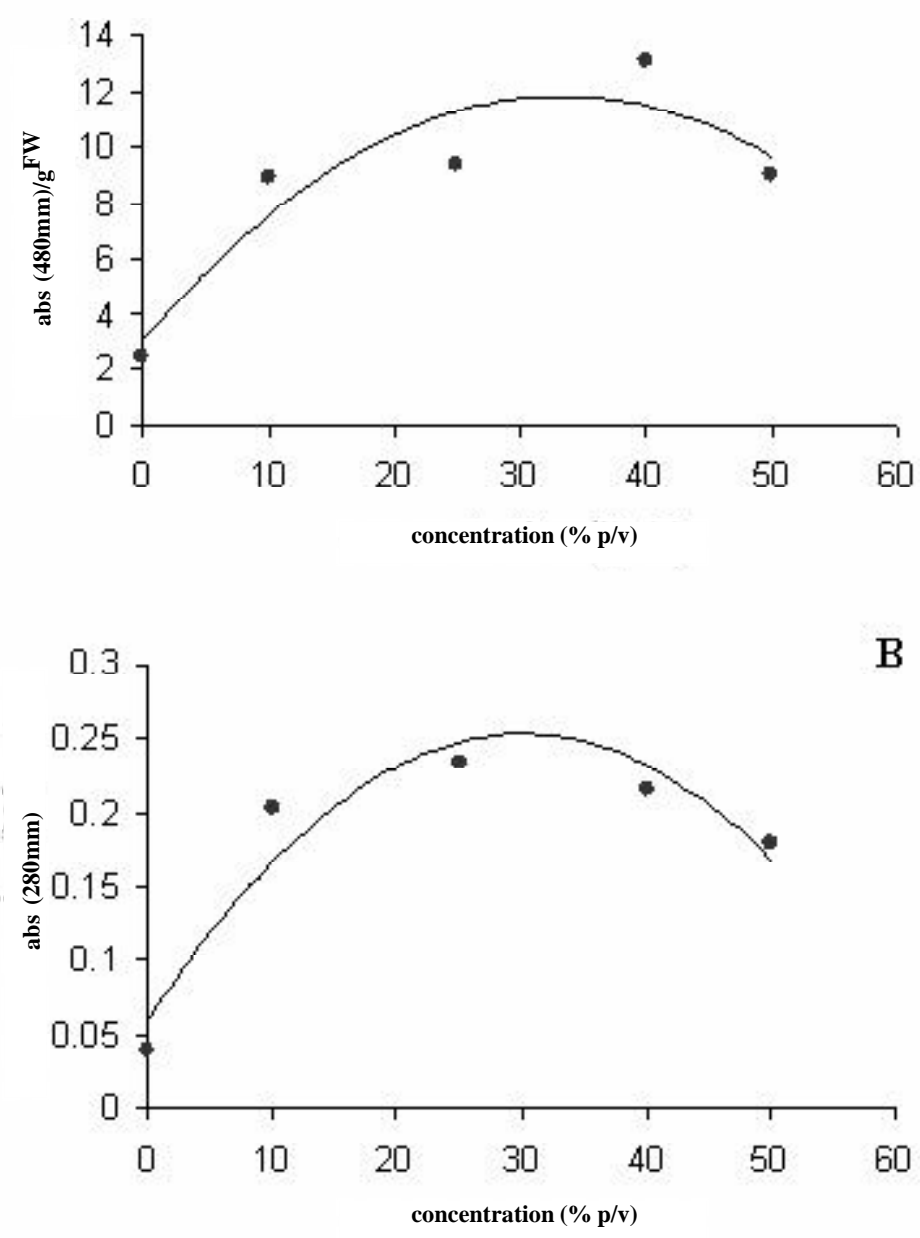

Figure 1. Phytoalexin production in soybean and sorghum following the treatment with Ocimum gratissimum aqueous extracts. Distilled water was used as control. Values are means of three repetitions. (A): 3deoxyanthocyanidins were extracted from sorghum mesocotyls incubated with the extracts at $25{ }^{\circ} \mathrm{C}$ for $60 \mathrm{~h}$, using methanol $80 \%$. Phytoalexins were detected in the methanolic solutions and expressed as absorbance units at $480 \mathrm{~nm}$ per gram of fresh weight. (B): Glyceollins were extracted from soybean cotyledons incubated with the extracts at $25{ }^{\circ} \mathrm{C}$ for $20 \mathrm{~h}$ in the dark. Phytoalexins were detected in the aqueous solution obtained by the agitation of cotyledons in water and expressed as absorbance units at $285 \mathrm{~nm}$.

reduced on the treated inoculated plants probably due to systemic induction, but the answer was more results dependent on time of application than on extract concentration. For other plant extracts, including cucumber, a dose response study indicated that increasing concentrations generally produce increasing levels of systemic resistance in cucumber to Colletotrichum lagenarium and that some are phytotoxic at higher concentrations (14). We did not observe a dose response, but there were no signs of phytotoxicity in response to the concentration tested of the extract either.

Many products have been shown to induce resistance responses in cucumber, especially following inoculation with Sphaerotheca fuliginea, Cladosporium cucumerinum and Colletotrichum lagenarium. Examples include Acibenzolar-S-Metyl (22), salicylic acid and its derivatives (13). Among elicitors of plant origin, the best studied example is Reynoutria sachalinensis leaf extracts (12). Resistance

\begin{tabular}{lll}
\hline Time (dbi) & First Leaves & Second Leaves \\
\hline 0 & $10.56 \pm 2.41$ & $11.25 \pm 11.09$ \\
1 & $11.13 \pm 2.98$ & $4.38 \pm 1.74$ \\
3 & $6.38 \pm 1.76$ & $2.44 \pm 1.01$ \\
7 & $8.19 \pm 4.88$ & $4.38 \pm 2.20$ \\
Control & $1.33 \pm 1.53$ & $2.17 \pm 0.65$ \\
\hline
\end{tabular}

Table 2. Chitinase activity on the second true leaves of cucumber seedlings treated with Ocimum gratissimum leaf extracts following inoculation with Colletotrichum lagenarium. Aqueous extracts at 10, 25, 40 and 50\% (w/v) were applied on the first true leaves 7, 3, 1 and 0 days before inoculation of both leaves with a suspension of $1 \times 10^{5}$ conidia. $\mathrm{mL}^{-1}$. Activity was determined from $2.5 \mathrm{~cm}^{2}$ leaf discs collected 10 days after inoculation. CM-chitin-RBV was used as substrate. Activity was expressed as the enzyme specific activity (EA), given by the equation $E A=E U \times \mathrm{mg}^{\text {protein }}{ }^{-1}$ (see Materials and Methods). Values are means of three repetitions, followed by standard deviations.

\begin{tabular}{lcccc}
\hline Time (dbi) & \multicolumn{4}{c}{ Concentration $(\% \mathbf{w} / \mathbf{v})$} \\
\hline 0 & $\mathbf{1 0}$ & $\mathbf{2 5}$ & $\mathbf{4 0}$ & $\mathbf{5 0}$ \\
\hline 1 & $4.28 \pm 0.34$ & $3.95 \pm 0.70$ & $4.01 \pm 0.67$ & $3.59 \pm 0.72$ \\
3 & $3.29 \pm 0.58$ & $7.44 \pm 3.03$ & $4.41 \pm 0.77$ & $4.21 \pm 1.13$ \\
7 & $3.00 \pm 0.40$ & $2.92 \pm 0.54$ & $3.02 \pm 0.61$ & $3.00 \pm 0.63$ \\
\hline
\end{tabular}

induction in cucumber has also been obtained by the application of PGPR preparations, especially from Pseudomonas sp. and Bacillus sp. (24).

Cucumber defence responses include decreases in disease incidence and/or severity and have been frequently associated with the induction of peroxidases and the PR-proteins b-1,3-glucanases and chitinases production (17). In particular, chitinase production has been associated to several other defense responses following various treatments (22). In fact, induced resistance in plants is a multi component system and also includes the ability of a plant to delay or avoid the entrance and/ or the subsequent activity of a pathogen in its tissues (15). In our study, maximum induction of plant defense response did not coincide with a smaller number of lesions, which indicates that chitinase may not are the sole determinants in the resistance reaction in this system. However increases of induced plant defense were observed following almost all treatments compared to the control, suggesting that may be other mechanisms and operating along with the chitinase production.

Previous experiments with $O$. gratissimum protein rich fractions showed that constituents were not anti-fungal, showing no effect on C. lagenarium spore germination or apressoria formation (10). If there is a decrease in disease severity, it might be possible that the tested extracts could be inducing cucumber plants to produce defense compounds themselves, i.e. phytoalexins. Recent studies have shown that the production of phytoalexins of phenolic and flavonoid nature in response to different agents is a common induction response in cucumber (12). Preliminary anatomical observations have shown the accumulation of granules of phenolic nature in treated, inoculated 
cucumber hypocotyls (10), which suggests that penetration and/or initial development of the pathogen might be affected.

Many different substances seem to trigger responses in cucumber, with no apparent common structural features among a compound that does or does not induce systemic resistance (14). Not surprisingly, in most in previous studies plants parts, of $O$. gratissimum including the leaves, showed a very complex chemical composition. Considering only distilled oils, three groups could be distinguished based on high contents of eugenol, thymol or geraniol (9). Other components have been cited in essential oils, such as $p$ cimene, a-copene, g-selinene and g-terpinene and spatunelol and myrcene (27). O. gratissimum is also frequently cited for the flavonoids cirsimaritine, isotimusine, xantomicrol and luteolin (27) and for high contents of calcium (19).

In conclusion, the application of $O$. gratissimum leaf extracts can lead to certain defense responses in soybean, sorghum and cucumber, which may result from the combination of a direct antimicrobial activity of essential oils and the elicitation of defense responses induced by the extracts components. Further experiments are necessary to determine the best times of application and/or extract concentrations. Of equal importance is the elucidation of the extract components. Still, the potential of $O$. gratissimum extract an elicitors of resistance in these plants should not be discarded.

\section{ACKNOWLEDGEMENTS}

This work is a part of the first author's master dissertation and was supported by a fellowship from Conselho Nacional de Desenvolvimento Científico e Tecnológico (CNPq). The authors also thank Ana Cristina Fiori, Carla Moreira, Márcia Motoyama, Reinaldo Bernardo and Rudimar Maffacioli.

\section{REFERENCES}

1. Amadioha, A.C.; Obi, V.I.. Control of anthracnose disease of cowpea by Cybopogon citratus and Ocimum gratissimum. Acta Phytopathologica et Entomologica Hungarica, Budapest, v.34, p.85-89, 1999.

2. Ansari, M.M. Control of sheath blight of rice by plant extracts. Indian Phytopathology, Nova Delhi, v.48, p.268-270, 1995.

3. Awuah, R.T. In vivo use of extracts of Ocimum gratissimum and Cymbopogon citratus against Phytophthora palmivora causing blackpod disease of cocoa. Annals of Applied Biology, Oxford, v.124, n.1, p.173-178, 1994.

4. Ayers, A.R.; Ebel, J.; Finelli, F.; Berger, N.; Albersheim, P. Hostpathogen interactions. IX. Quantitative assays of elicitor activity and characterization of the elicitor present in the extracellular medium of cultures of Phytophthora megasperma var. sojae. Plant Physiology, Hanover, v.57, n.5, p.751, 1976.

5. Balbi-Peña, M.I.; Becker A.; Stangarlin, J.R.; Franzener G.; Lopes M.C.; Schwan-Estrada, K.R.F. Controle de Alternaria solani em tomateiro por extratos de Curcuma longa e curcumina - I. Avaliação in vitro. Fitopatologia Brasileira, Brasília, v.31, p.310-314, 2006.

6. Bonaldo, S.M.; Schwan-Estrada, K.R.F.; Stangarlin, J.R.; Tessmann, D.J.; Scapim, C,A. Fungitoxicidade, atividade eliciadora de fitoalexinas e proteção de pepino contra Colletotrichum lagenarium, pelo extrato aquoso de Eucalyptus citriodora. Fitopatologia Brasileira, Brasília, v.29, n.2, p.128-134, 2004.

7. Bradford, M.M. A rapid and sensitive method for the quantitation of microgram quantities of protein utilizing the principle of pro- tein-dye binding. Analytical Biochemistry, San Diego, v.72, n.1/2,, p.248-254, 1976.

8. Braga, R.B.; Dietrich, S.M.C. Phytoalexin-inducing oligosaccharins from the cell walls of tropical Rubiaceae. Brazilian Journal Plant Physiology, Viçosa, v.10, p.79-84, 1998.

9. Charles, D.J.; Simon, J.E. A new geraniol chemotype of Ocimum gratissimum L. Journal Essential Oil Research, Rio de Janeiro, v.4, p.231-234, 1992.

10. Colpas, F.T. Atividade eliciadora de extratos de alfavacacravo (Ocimum gratissimum L.). 2002. 65 p. Dissertação (Mestrado em Produção Vegetal) - Universidade Estadual de Maringá, Maringá.

11. Cutter EG. Anatomia vegetal. Parte I - Células e tecidos 2.ed. São Paulo: Roca, 1986. 304p.

12. Fofana, B.; McNally, D.J.; Labbé, C. et al. Milsana-induced resistance in powdery mildew-infected cucumber plants correlates with the induction of chalcone synthase and chalcone isomerase. Physiological Molecular Plant Patholology, New York, v.61, n.2, p.121-132, 2002

13. Fauth, M.; Merten, A.; Hahn, M.G.; Jeblick, W.; Kauss, H. Competence for elicitation of $\mathrm{H} \mathrm{O}$ in hypocotyls of cucumber is induced by breaching the cuticle ${ }^{2}$ and is enhanced by salicylic acid. Plant Physiology, Hanover, v.110, p.347-354, 1996.

14. Fought, L.; Kuc, J.A. Lack of specificity in plant extracts and chemicals as inducers of systemic resistance in cucumber plants to anthracnose. Journal Phytopathology, Berlin, v.144, p.1-6, 1996.

15. Goodman, R.N.; Király, Z.; Wood, K.R. The biochemistry and physiology of plant disease. Columbia: University of Missouri Press, 1986

16. Graham, T.L.; Graham, M.Y. Signaling in soybean phenylpropanoid responses. Plant Physiology, Hanover, v.110, p.1123-1133, 1996.

17. Hammerschimidt R. Induced disease resistance: how do induced plants stop pathogens? Physiological Molecular Plant Pathology, New York, v.55, p.77-84, 1999.

18. Kessmann, H.; Staub, T.; Hofmann, C. et al. Induction of systemic acquired disease resistance in plants by chemicals. Annual Review Phytopathology, Palo Alto, v.32, p.439-459, 1994.

19. Lopes, M.F.G.; Almeida, M.M.B.; Nogueira, C.M.D.; Morais, N.M.T. Caracterização físico-química de algumas espécies de plantas medicinais. Revista Brasileira de Plantas Medicinais, Botucatu, v.4, p.95-98, 2001.

20. Lyon, G.D.; Reglinski, T.; Newton, A.C. Novel disease control compounds: the potential to 'immunize' plants against infection. Plant Pathology, Oxford, v.44, p.407-427, 1996.

21. Modolo, L.V.; Cunha, F.Q.; Braga, M.R.; Salgado, I. Nitric oxide synthase-mediated phytoalexin accumulation in soybean cotyledons in response to the Diaporthe phaseolorum f. sp. meridionalis elicitor. Plant Physiology, Hanover, v.130, p.1288-1297, 2002.

22. Narusaka, Y.; Narusaka, M.; Horio, T.; Ishii, H. Comparison of local and systemic induction of acquired disease resistance in cucumber plants treated with Benzothiadiazoles or salicylic acid. Plant Cell Physiology, Oxford, v.40, p.388-395, 1999.

23. Nicholson, R.L.; Kollipara, S.S.; Vincent, J.R.; Lyons, P.C.; Cadena-Gomez, G. Phytoalexin synthesis by the sorghum mesocotyl in response to infection by pathogenic and non pathogenic fungi. Proceedings of the National Academy Sciences USA, Washington, v.84, p.5520, 1987.

24. Ongena, M.; Duby, F.; Jourdan, E. et al. Bacillus subtilis M4 decreases plant susceptibility towards fungal pathogens by increasing host resistance associated with differential gene expression. Applied Microbiol Biotechnology, Berlin, v.67, p.692698, 2005.

25. Pelicice, F.M.; Dietrich, S.M.C.; Braga, M.R. Phytoalexin response of fifteen Brazilian soybean cultivars. Brazilian Journal Plant Physiology, Brasília, v.12, p.45-53, 2000.

26. Stangarlin, J.R.; Pascholati, S.F.; Franzener, G. Phenols, b-1,3 glucanase, chitinase and phenylalanine ammonia-lyase activities 
in infection sites of Exserohilum turcicum in maize genotypes. Summa Phytopathologica, Botucatu, v.31, p.261-267, 2005

27. Vieira, R.F.; Greyer, R.J.; Paton, A.; Simon, J.E. Genetic diversity of Ocimum gratissimum L. based on volatile oil constituents, flavonoids and RAPD markers. Biochemistry Systematics and Ecology, Amsterdam, v.29, p.287-304, 2001.

28. Wirth, S.J.; Wolf, G.A. Dye-labelled substrates for the assay and detection of chitinase and lysozyme activity. Journal Microbi- ological Methods, Shanoon, v.12, p.197-205, 1990.

29. Wulff, N.A.; Pascholati, S.F. Preparações de Saccharomyces cerevisiae elicitoras de fitoalexinas em mesocótilos de sorgo. Scientia Agricola, Piracicaba, v.55, p.138-143, 1998.

30. Yamaoka, N.; Lyons, P.C.; Hipskind, J.; Nicholson, R.L. Elicitor of sorghum synthesis from Colletotrichum graminicola. Physiologycal Molecular Plant Pathology, New York, v.37, p.255270,1990 . 